\author{
Marzena Cichosz \\ University of Wrocław (Poland) \\ Łukasz Tomczak \\ University of Szczecin (Poland)
}

\title{
Third Place is a Charm. Women in the 2010, 2014 and 2018 Regional Assembly Elections in Poland
}

\begin{abstract}
The analysis of women's participation in elections has long been an important theme within political studies. Scholars have looked at factors that affect women's participation in politics in general, as well as their decisions to run in parliamentary or regional elections. In 2011, as the second Central and Eastern Europe country (the first being Slovenia), Poland introduced gender quotas into the proportional electoral system. Researchers looking into the consequences of such systemic solutions in various countries have established that the intended goal of increasing the proportion of women in legislative bodies has not always been achieved. In fact, the outcomes have varied widely. Such discrepancies invite further examination. The presented study focuses on regional assembly elections in Poland between 2010 and 2018. The article elaborates on and complements the results of the authors' prior work on the 2010 and 2014 elections. The research looks at how effective women were in winning the available mandates, what were their placements and which parties managed to get most women into the assemblies.
\end{abstract}

Keywords: regional elections, women's rights, Poland, gender equality

\section{Introduction}

The analysis of women's participation in elections has long been an important theme within political studies (for example: Krook, 2004; Norris, 2006; Krook, 2007; Tripp \& Kang, 2008; Dahlerup \& Freidenvall, 2010). In Poland, the subject has been tackled primarily by M. Fuszara's research team, commissioned by the Institute of Public Affairs $(2012,2013)$. Scholars have looked at factors that affect women's participation in politics in general (see for example: Kotlarska-Michalska, 2011; Lesiewicz, 2011), as well as their decisions to run in parliamentary or regional elections (e.g. Chełstowska et al., 2015; Posyłek, 2015). In 2011, as the second Central and Eastern Europe country (the first being Slovenia), Poland introduced gender quotas 
into the proportional electoral system (Marszałek-Kawa, Plecka, 2018). Researchers looking into the consequences of such systemic solutions in various countries have established that the intended goal of increasing the proportion of women in legislative bodies has not always been achieved. In fact, the outcomes have varied widely. In some cases, the quota system made a substantial difference (Dahlerup, Freidenvall, 2005). In others, the change was only marginal (Htun, 2002; Murray, 2004). There were also instances where the number of women serving as MPs has actually decreased (Araújo, 2003). Such discrepancies invite further examination. The study presented here focuses on regional assembly elections in Poland between 2010 and 2018. The article elaborates on and complements the results of the authors prior work on the 2010 and 2014 elections (Cichosz, Tomczak, 2018, pp. 25-37).

The 2018 regional election stands out as a potential subject of examination for several reasons. First of all, it was the first election after Law and Justice-led coalition won a majority of seats in the parliamentary election and formed a cabinet on its own. Consequently, Law and Justice (PiS) was able to take over a number of posts in public administration and state-owned companies - a convenience the party was quick to take advantage of (Kopińska, 2018). Over the subsequent years, the media uncovered several cases where PiS members enjoyed very high salaries by holding multiple posts in local governments and state-owned companies simultaneously. In response to that, a couple of months before the 2018 election the party's leadership took the decision to ban from its lists all members who worked for state-owned companies (tol/sta TVP24, 2018). Thus, PiS de facto decreased the number of potential candidates by eliminating all who had already been assigned a function. As regional elections often serve to verify a party's grassroot strength, it might have been a momentous choice. Did it prove beneficial to the women within PiS' ranks? Were they better positioned to fill the gaps on the slates?

Another factor that made the 2018 election unique was the amendment to the electoral statute enacted in January 2018. Although the key tenet of the statute - the proportional system - was maintained, the reform introduced a change that would affect women's presence on the lists. According to the new regulation, the maximum number of candidates to be registered by a single party would equal the number of mandates available in a given constituency, plus two (art. 457, The Electoral Statute Act).

The main research questions addressed in this are article refer to:

- the number of women on all parties' lists in the regional assembly elections between 2010 and 2018;

- the number of women who occupied one of the top three spots on the lists registered by the largest committees in each region.

Narrowing the scope of analysis to the top three placements can be justified by the realities of regional elections - it has been proven that approximately $80 \%$ of seats are usually taken by candidates who run from a top-three spot. Ergo, candidates who are handed high positions on the lists enjoy an advantage right from the start and are likely to beat their lower-placed rivals. 
This part of the analysis encompasses predominantly the largest registered lists, i.e. the four slates formed, independently or in coalition, by the largest political parties: Law and Justice (PiS), the Civic Platform (PO), Polish People's Party (PSL) and the Democratic Left Alliance (SLD). Additionally, it features those smaller, regional lists from which candidates have been elected to sit on the assemblies.

Since the number of constituencies varied between 2010 and 2018 and the structure of electoral rivalry shifted over time, the number of lists examined for each election in different: in 2010-373, 2014-372, 2018-385. The same reason prompted the authors to present most data in the form of percentages, so that comparisons between subsequent elections are possible.

Finally, the research looks at how effective women were in winning the available mandates, what were their placements and which parties managed to get most women into the assemblies.

\section{Women's Placements on the Lists}

A quick look at the number of women who ran in successive elections reveals an overall increase, with the biggest jump between the 2010 and the 2014 elections (that is when the quota system was introduced).

Table 1. Percentage of women on the lists for the 2010, 2014 and 2018 regional assembly elections

\begin{tabular}{llllll}
\hline Province & \multicolumn{2}{l}{ Women on the lists (\%) } & \multicolumn{3}{c}{$\begin{array}{l}\text { Increase/decrease } \\
\text { (percentage points) }\end{array}$} \\
\cline { 2 - 6 } & $\mathbf{2 0 1 0}$ & $\mathbf{2 0 1 4}$ & $\mathbf{2 0 1 8}$ & $\mathbf{2 0 1 0 / 2 0 1 4}$ & $\mathbf{2 0 1 4 / 2 0 1 8}$ \\
\hline 1. dolnośląskie & 28,4 & 43,4 & 46,0 & $+15,0$ & $+2,6$ \\
\hline 2. kujawsko-pomorskie & 30,5 & 45,7 & 46,4 & $+15,2$ & $+0,7$ \\
\hline 3. lubelskie & 28,2 & 44,1 & 44,9 & $+15,9$ & $+0,8$ \\
\hline 4. lubuskie & 28,7 & 44,8 & 44,5 & $+16,1$ & $-0,3$ \\
\hline 5. hódzkie & 31,8 & 44,9 & 45,2 & $+13,1$ & $+0,3$ \\
\hline 6. małopolskie & 27,5 & 43,0 & 45,2 & $+15,5$ & $+2,2$ \\
\hline 7. mazowieckie & 34,3 & 44,7 & 46,3 & $+10,4$ & $+1,3$ \\
\hline 8. opolskie & 28,2 & 44,2 & 45,5 & $+16,0$ & $+1,3$ \\
\hline 9. podkarpackie & 27,0 & 44,2 & 44,3 & $+17,2$ & $+0,1$ \\
\hline 10. podlaskie & 18,9 & 45,3 & 44,2 & $+26,4$ & $-1,1$ \\
\hline 11. pomorskie & 33,1 & 41,8 & 46,6 & $+8,7$ & $+4,8$ \\
\hline 12. śląskie & 29,7 & 44,7 & 46,8 & $+15,0$ & $+2,1$ \\
\hline 13. świętokrzyskie & 30,7 & 45,1 & 46,7 & $+14,4$ & $+1,6$ \\
\hline 14. warmińsko-mazurskie & 30,2 & 47,1 & 46,7 & $+16,9$ & $-0,4$ \\
\hline 15. wielkopolskie & 30,0 & 45,1 & 48,0 & $+15,1$ & $+2,9$ \\
\hline 16. zachodniopomorskie & 32,1 & 43,9 & 44,1 & $+11,8$ & $+0,2$ \\
\hline Polska & 29,8 & 44,5 & 45,8 & $+14,7$ & $+1,3$ \\
\hline
\end{tabular}

Source: Own work, based on data published by the National Electoral Committee. 
Compared to the 2010 election, the 2014 race saw 14,7 percent more women among all candidates. Between 2014 and 2018 the increase across the whole country was far slower only a 1,3 percent - with the highest uptick recorded in the pomorskie, wielkopolskie and dolnośląskie provinces. In three regions women's participation actually decreased by a small margin. In both the 2014 and 2018 elections, women constituted over 35\% candidates, which was the target specified in the quota system. The fact the target was met could be attributed to, among other factors, the size of constituencies. In case of small constituencies where lists are limited to five candidates, including two women is enough, as they amount to $40 \%$ of a given slate. In the most recent regional election, women took nearly half of all places on the lists, which seems a satisfactory development for the proponents of parity.

When one considers women's chances to run successful candidacies, one needs to look at their numbers on the lists registered by the parties with the largest voter base. One also needs to take account of where they were ranked on the slates.

Upon examination of the 2010, 2014 and 2018 elections, the first conclusion is that women gradually climbed up the lists, gaining more share of the top placements. In 2010 the proportion of women candidates ranked in the top three spots of their respective lists was at $23,5 \%$. Four years later it went up to $28,4 \%$. In 2018, it reached 32,5\% - almost (though not quite) the percentage targeted by lawmakers.

A closer look at the issue reveals a somewhat different perspective. It turns out that the extent to which the quota was (or was not) met varied widely depending on whether one considers the top, second or third spot on the lists. The share of women among candidates leading their respective slates went up from 14,5\% in 2010 to 20,5\% in 2018. For the second spot, the same statistic read $26,3 \%$ in $2010,35 \%$ in 2014 and $33,7 \%$ in 2018 . The biggest increase was recorded among third-ranked candidates: from $29,8 \%$ in 2010 to $32,3 \%$ in 2014 and $43,2 \%$ in 2018 . The last number is almost as high as women's overall participation in the 2018 election, which stood at $45,8 \%$ (see: Graph 1).

When examining differences between regions, one can observe four patterns that described women's presence among top three candidates on their respective lists:

- regions where the percentage of women exceeded the countrywide average in every election between 2010 and 2018 (mazowieckie, śląskie);

- regions where this number was in every case below the countrywide average (lubuskie, opolskie, podkarpackie, podlaskie, świętokrzyskie);

- regions where the percentage was above the countrywide average in 2014 and 2018, but below it in 2010 (lubelskie, pomorskie, warmińsko-mazurskie, wielkopolskie);

- a reverse situation, i.e. where the percentage had been above the average in 2010, but dropped below it after introducing the quota system (dolnośląskie, kujawskopomorskie, małopolskie, zachodniopomorskie).

The only province that has not fallen into any of the four patterns is łódzkie, where the 2010 and 2018 elections saw the percentage of women among top candidates above 


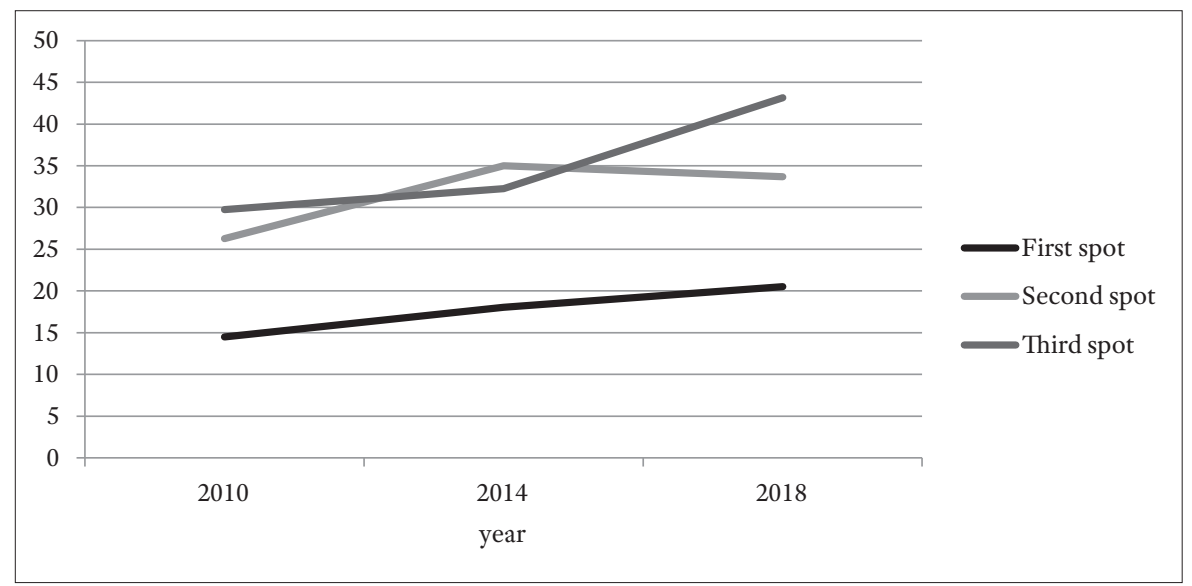

Graph 1. Percentage of women among candidates registered by the largest political parties, 2010-2018.

Source: Own work, based on data published by the National Electoral Committee.

the countrywide average, while in 2014 it was significantly lower. The emergence of such patterns could be related to the voter base, organizational culture and leadership in the regional structures of the examined parties. Top spots on the lists are typically granted to women who have already developed a substantial political / social capital, be it externally (where it may rely on public recognition) or internally, within their organizations (see also: Druciarek, Przybysz, Przybysz, 2019, pp. 22-28; Plecka, 2018).

\section{Women as Candidates of Selected Nationwide Political Parties}

In parallel to the presented analysis, the authors have isolated certain political parties (or their coalitions) and examined them in an analogical fashion. In the case of slates registered by these formations, the biggest increase in women's participation occurred between the 2010 and the 2014 elections (see: Table 2), undoubtedly as a consequence of the quota system that was introduced during that period. A further growth, albeit much less rapid, could be observed in the 2018 election - this one could be attributed to the aforementioned change in the Electoral Statute Act which limited the number of registered candidates.

An examination of regional slates suggests that the Civic Platform leads the way in promoting women as number one candidates. In all three analyzed elections, the party consistently stood out among all the competitors in this respect. In particular, the 2014 election showcased the Civic Platform's progressive approach, as women took $28 \%$ of number one spots available in the constituencies across the country. Four years later, that number dropped slightly, down to 25\% (see: Graph 2). 
Table 2. Women candidates registered by selected nationwide political parties for the 2018 regional election, 2010, 2014 and 2018.

\begin{tabular}{lcccc}
\hline & PO $^{*}$ & PiS & PSL & SLD $^{\text {** }}$ \\
\hline 2010 & 26,2 & 24,4 & 23,2 & 32,2 \\
\hline 2014 & 43,9 & 42,4 & 42,8 & 44,3 \\
\hline 2018 & 45,0 & 43,0 & 45,0 & 46,0 \\
\hline
\end{tabular}

* In 2018, a coalition registered under the name of KKW Platforma Nowoczesna Koalicja Obywatelska.

** In 2010, the Democratic Left Alliance; in 2014 and 2018, a coalition registered under the name of KKW SLD Lewica Razem.

Source: For the 2010 and 2014 elections - own work, based on data published by the National Electoral Committee; for the 2018 election - data published by the National Electoral Committee.

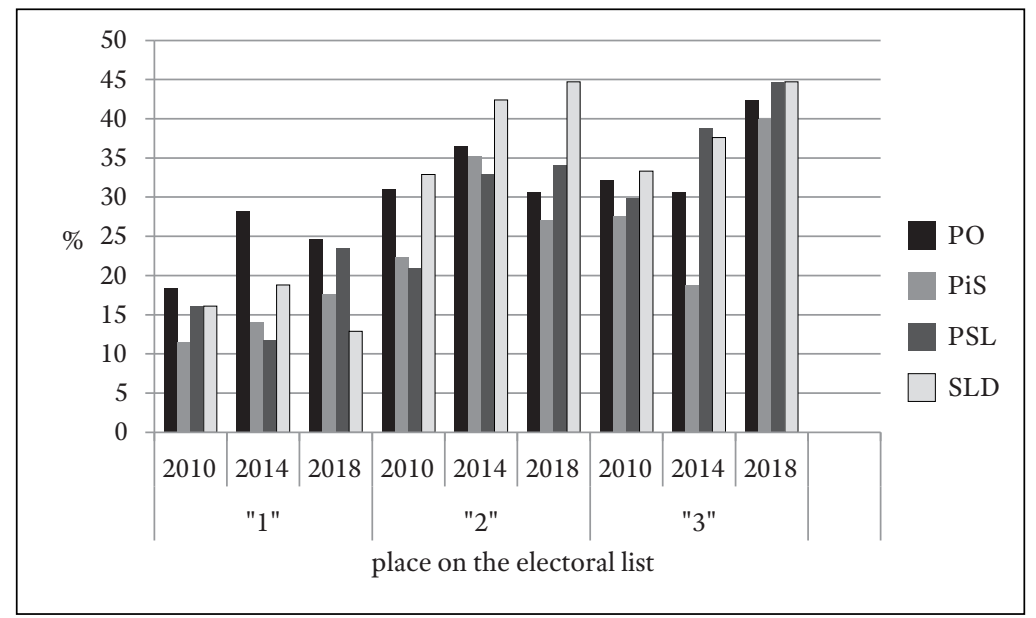

Graph 2. Women's placement on the slates registered by major Polish political parties or their coalitions.

Source: Own work, based on data published by the National Electoral Committee.

In the cases of Law and Justice as well as Polish People's Party, the overall number of women heading the slates also increased but remained well below PO's levels: $18 \%$ for PiS and 23\% for PSL. As far as second spots are concerned, a significant increase occurred in the 2014 elections. The differences between the 2014 and 2018 elections are far less noticeable. A more impressive increase can be observed with regard to third places on the slates. In 2018, women constituted between 40 and $45 \%$ of all third-ranked candidates on the lists registered by the four examined parties. Interestingly, the authors could discern (albeit the observation does not apply to all constituencies) a certain distinct strategy adopted by the Democratic Left Alliance. In the case of SLD, the number of second-ranked women candidates was comparatively high throughout the analyzed period. This was because the 
party decided to adopt a method of placing men and women alternately on its slates. As can be inferred from the graph, it meant that by 2018 men were significantly overrepresented among SLD's top candidates in comparison to other major formations.

\section{Election Results and Women's Presence in Regional Assemblies}

Overall, the number of women who won seats in regional assemblies in each election is as follows: 126 in 2010, 128 in 2014 and 158 in 2018. If one compares the results in 2010 and 2014, it seems that the introduction of the quota system did not lead to an increased representation of women - their numbers (that corresponded to $21,8 \%$ and $23,1 \%$ of all mandates for 2010 and 2014 respectively) in assemblies remained fairly similar. Such status quo was finally altered in 2018, when both the number and percentage of women occupying seats in those regional bodies grew noticeably - 30 more mandates translated into a rise of 5,5 percentage point (up to 28,5\%). Still, the result meant that the share of seats won by women did not match their participation on the lists.

Table 3. Percentage of women in regional assemblies: 2010, 2014 and 2018.

\begin{tabular}{cccccc}
\hline $\begin{array}{c}\text { Region } \\
\text { (province) }\end{array}$ & \multicolumn{3}{c}{ Percentage of women } & \multicolumn{2}{c}{ Increase / decrease } \\
\cline { 2 - 6 } & 2010 & 2014 & 2018 & $2010 / 2014$ & $2014 / 2018$ \\
\hline 1 & 27,8 & 22,2 & 22,2 & $-5,6$ & 0,0 \\
\hline 2 & 24,2 & 18,2 & 16,7 & $-6,0$ & -1.5 \\
\hline 4 & 18,2 & 18,2 & 18,2 & 0,0 & 0.0 \\
\hline 5 & 20,0 & 16,7 & 36,7 & $-3,3$ & $+20,0$ \\
\hline 6 & 36,1 & 33,3 & 42,4 & $-2,8$ & $+9,1$ \\
\hline 7 & 20,5 & 20,5 & 23,1 & 0,0 & $+2,6$ \\
\hline 8 & 33,3 & 41,2 & 27,4 & $+7,9$ & $-13,8$ \\
\hline 9 & 16,7 & 16,7 & 26,7 & 0,0 & $+10,0$ \\
\hline 10 & 12,1 & 21,2 & 27,3 & $+9,1$ & $+6,1$ \\
\hline 11 & 6,7 & 16,7 & 23,3 & $+10,0$ & +6.6 \\
\hline 12 & 27,3 & 15,2 & 36,4 & $-12,1$ & $+21,2$ \\
\hline 13 & 27,1 & 28,9 & 37,8 & $+1,8$ & $+8,9$ \\
\hline 14 & 10,0 & 10,0 & 23,3 & 0,0 & $+13,3$ \\
\hline 15 & 23,3 & 26,7 & 30,0 & $+3,4$ & $+3,3$ \\
\hline 16 & 15,4 & 25,6 & 38,5 & $+10,2$ & $+12,9$ \\
\hline Poland & 30,0 & 23,3 & 23,3 & $-6,7$ & 0,0 \\
\hline & 21,8 & 23,1 & 28,6 & $+1,3$ & $+5,5$ \\
\hline
\end{tabular}

Source: own calculations based on data published by the National Electoral Committee. 
The difference between the proportion of women on the lists and their share of mandates in assemblies varied widely from one election to the next. In 2010 it stood at 8 percentage points, in 2014 it rose to 21,4 , while in 2018 it fell to 17,2. Interestingly, the major increase occurred after the introduction of the quota system. This means that with the system in place, male candidates were comparatively more successful in winning mandates than women.

When it comes to the proportion of women among all deputies to the regional assemblies, before 2018 there were only two instances in which it exceeded 35\%: in 2010 in the łódzkie province and in 2014 in the mazowieckie province. In 2018, the situation changed, as five assemblies had over 35\% share of women deputies (note: this particular percentage is referenced here because it was the proportion of women among candidates mandated by the quota system). If one lowers the bar down to $30 \%$, statistics are only slightly better. In 2010 , women won over $30 \%$ of mandates in three provinces. In 2014, it happened in two regions, while in 2018 - six.

A comparison of the 2010 and 2014 results reveals that women's participation in assemblies actually decreased in six provinces. In four others it remained unchanged. Six regions recorded an increase. After the 2018 election, the situation was as follows: two assemblies had less women deputies, while eleven gained more. In three provinces the proportion stayed even. The only region where the share of women among deputies remained constant throughout the analyzed period was lubelskie. A systematic increase occurred in five provinces. The highest overall jump between 2010 and 2018 was recorded in the wielkopolskie province: 23,1 percentage points.

The number of women representing political parties who won mandates to regional assemblies did not change between 2010 and 2014: there were 125 of them. After the 2018 election, it rose to 155 .

If one considers candidates registered by the largest political parties, the Civic Platform stands out as an example of consistency. The number of women elected from PO's lists remained fairly constant: 67, 62 and 66 in 2010, 2014 and 2018 respectively. In 2010 and 2014, PO's members amounted to roughly half of all successful women candidates. 2018 saw a twofold increase in the number of women elected from Law and Justice's lists. Since 2018, PiS has the largest representation of women in regional assemblies among all parties ( $46,2 \%$ seats). Notably, PiS registered a higher number of women candidates in each successive election. On the whole, a large majority of women elected to the assemblies were representatives of the two largest formations. In 2010, 75,4\% of all successful women candidates were registered by either PO or PiS. For the 2014 election, the corresponding number stood at $73,4 \%$, while for 2018 - at $88 \%$.

The numbers of mandates won by women who led the slates of their respective parties in 2010, 2014 and 2018 are fairly close. Of all women who ran a successful bid in the 2010 regional elections, 31,7\% were those who occupied top spots on the lists. For the 2014 elec- 
Table 4. Mandates won by women representing each political party.

\begin{tabular}{lccc}
\hline Political party & $\mathbf{2 0 1 0}$ & $\mathbf{2 0 1 4}$ & $\mathbf{2 0 1 8}$ \\
\hline PO/KO & 67 & 62 & 66 \\
\hline PiS & 28 & 32 & 73 \\
\hline PSL & 13 & 30 & 15 \\
\hline SLD LR & 17 & 1 & 1 \\
\hline others & 1 & 3 & 3 \\
\hline
\end{tabular}

Source: Own calculations based on data published by the National Electoral Committee.

tion, the same statistic stood at 35,9\%, while in 2018 - at 30,4\%. The decreased share in the latest regional election reflects the fact that more women won mandates, while the number of successful no. 1 women candidates remained roughly identical.

Table 5. Slate placements of successful women candidates in the 2010, 2014 and 2018 elections, listed by province.

\begin{tabular}{|c|c|c|c|c|c|c|c|c|c|}
\hline \multirow[t]{3}{*}{ Province } & \multicolumn{9}{|c|}{ Number of mandates won from a given placement } \\
\hline & \multicolumn{3}{|c|}{ I } & \multicolumn{3}{|c|}{ II-V } & \multicolumn{3}{|c|}{ VI and lower } \\
\hline & 2010 & 2014 & 2018 & 2010 & 2014 & 2018 & 2010 & 2014 & 2018 \\
\hline 1 & 3 & 4 & 1 & 7 & 4 & 7 & 0 & 0 & 0 \\
\hline 2 & 3 & 2 & 4 & 5 & 3 & 1 & 0 & 1 & 0 \\
\hline 3 & 2 & 1 & 3 & 4 & 5 & 3 & 0 & 0 & 0 \\
\hline 4 & 2 & 1 & 5 & 3 & 3 & 5 & 1 & 1 & 1 \\
\hline 5 & 4 & 3 & 2 & 8 & 6 & 9 & 1 & 2 & 3 \\
\hline 6 & 2 & 4 & 3 & 5 & 3 & 6 & 1 & 1 & 0 \\
\hline 7 & 6 & 7 & 3 & 8 & 12 & 10 & 3 & 2 & 1 \\
\hline 8 & 3 & 3 & 2 & 2 & 2 & 5 & 0 & 0 & 1 \\
\hline 9 & 3 & 4 & 1 & 0 & 3 & 7 & 1 & 0 & 1 \\
\hline 10 & 1 & 1 & 2 & 1 & 3 & 3 & 0 & 1 & 2 \\
\hline 11 & 1 & 0 & 2 & 6 & 4 & 7 & 2 & 1 & 3 \\
\hline 12 & 4 & 4 & 4 & 7 & 8 & 11 & 2 & 1 & 2 \\
\hline 13 & 0 & 0 & 2 & 2 & 2 & 4 & 1 & 1 & 1 \\
\hline 14 & 4 & 4 & 5 & 2 & 4 & 2 & 1 & 0 & 2 \\
\hline 15 & 1 & 5 & 7 & 4 & 4 & 6 & 1 & 1 & 2 \\
\hline 16 & 1 & 3 & 2 & 7 & 4 & 4 & 1 & 0 & 1 \\
\hline Poland & 40 & 46 & 48 & 71 & 70 & 90 & 15 & 12 & 20 \\
\hline
\end{tabular}

Source: Own calculations based on data published by the National Electoral Committee.

Women who were placed between the second and fifth spot on their respective lists were similarly successful in winning seats in 2010 and 2014. For the 2018 election, that number grew. It was that portion of the slate that delivered most mandates for women all 
throughout the examined time period. In 2010,56,3\% of all successful women candidates ran from those spots. In 2014 , the proportion fell slightly down to $54,7 \%$, only to rise again in 2018 up to $56,9 \%$. If one adds no. 1 candidates to the statistics, the numbers are as follows; $88,1 \%$ in $2010,90,6 \%$ in 2014 and $87,3 \%$ in 2018 .

One important side note here is that the share of successful high- and low-ranked candidates, as described, depends on how many mandates a given party won in a given constituency. For instance, if at least two seats were won by a single formation, necessarily one of those will be taken by candidates placed second or lower on the slate. In the 2018 election, 40,5\% of women who were elected to the assemblies ran from either the second or the third spot. When one again adds top-placed candidates, that proportion increases to $70,89 \%$.

An interesting trend emerged with regard to the success of no. 1 women candidates. In 2010 , there were seven provinces where all women who led their parties' lists got elected to the assemblies. Four years later, the same thing happened only in three regions. In 2018, no province saw successful bids from all top-placed women candidates.

The importance of no. 1 spots on the lists become apparent when one looks at what percentage of candidates from each portion of the slate won mandates. In the analysis presented here, the lists are divided into three segments: the top spot, places from second to fifth, and sixth or lower. The authors have considered the lists registered by the largest political parties and those local formations that managed to win at least one mandate in their province.

The examination of results for the biggest political parties reveals that the number of successful top-placed women candidates increased over the analyzed period in the case of two formations: PiS and PSL. Women elected from places other than the first represented only the three most-supported parties.

Table 6. Slate placements of successful women candidates in the 2010, 2014 and 2018 elections, listed by political parties.

\begin{tabular}{|c|c|c|c|c|c|c|c|c|c|}
\hline \multirow[t]{3}{*}{ List } & \multicolumn{9}{|c|}{ Number of mandates won from a given placement } \\
\hline & \multicolumn{3}{|c|}{ I } & \multicolumn{3}{|c|}{ II - V } & \multicolumn{3}{|c|}{ VI and lower } \\
\hline & 2010 & 2014 & 2018 & 2010 & 2014 & 2018 & 2010 & 2014 & 2018 \\
\hline $\mathrm{PO} / \mathrm{KO}$ & 15 & 23 & 18 & 42 & 34 & 40 & 10 & 5 & 8 \\
\hline PiS & 10 & 11 & 16 & 15 & 19 & 47 & 3 & 2 & 10 \\
\hline PSL & 5 & 9 & 10 & 6 & 16 & 3 & 2 & 5 & 2 \\
\hline SLD LR & 10 & 1 & 1 & 7 & 0 & 0 & 0 & 0 & 0 \\
\hline others & 0 & 2 & 3 & 1 & 1 & 0 & 0 & 0 & 0 \\
\hline In total & 40 & 46 & 48 & 71 & 70 & 90 & 15 & 12 & 20 \\
\hline
\end{tabular}

Source: Own calculations based on data published by the National Electoral Committee.

In the case of the two strongest contenders - PO and PiS - it was rare for a top-ranked woman candidate not to win a seat. In 2010, of 16 women registered as no. 1 s by the Civic Platform, only one failed to succeed. In 2014, 23 out of 25 no. 1s were elected to the as- 
semblies. In 2018, the coalition led by PO placed 19 women at the top of its lists, with all but one winning mandates. Law and Justice was even more effective in this respect. In 2010 and 2018, all top-ranked women candidates representing that party were successful. The sole loss for a no.1 PiS candidate came in 2014.

\section{Conclusions}

The 2014 and 2018 regional elections saw increased numbers of women candidates - a development resulting largely from the amendments to the Electoral Statute Act. Women's participation exceeded the target set in the quota system, probably due (in part) to the size of constituencies.

In 2018, the leading political parties registered more (both in terms of number and proportion) women as their no. 1 candidates. Despite that, only around $20 \%$ of all top spots on the lists of the largest formations went to women. Where women's presence did noticeably increase was two steps down on the slate - over $40 \%$ of third places were granted to women. In general, it can be assumed that women's role in the regional structures of political parties still does not match men's.

In authors view, it can be hypothesized that placing women among top three candidates can, in the case of some political formations, be dictated by a pursuit of certain image. However, it is probably not deemed as a necessity. Since gender seems not to have any major impact on voters' choices, it is also not seen as a ticket to the top of the slate (Kwiatkowska, 2018, pp. 11-12).

Nonetheless, the largest parties did change their patterns of forming the slates. As noted before, the shift did not refer to the top-placed candidates - the number of women among them rose, but only by a small margin. A bigger shift occurred further down the slates. In 2010 , more women were ranked from second to fifth than sixth or lower. However, with the system in place, this proportion was reversed in the 2014 and 2018 elections. Such a development can be explained by the fact that women, in general, enjoy less political clout than men (Cwalina, Falkowski, 2005, p. 219) and are less involved in partisan politics. Poland does not have a large number of political parties. The introduction of the quota system might have pushed them to look for potential candidates among rank and file women members with no political capital, or even among people from outside the political realm. A similar observation has been made with regard to the parliamentary election (Flis, 2012, p. 94). Therefore, while the system did lead to increased presence of women on the slate, many of them were placed too low on the lists to stand a good chance of success.

In the case of regional elections, no link was observed between the quota system and the percentage of women among the elected deputies - the latter remained below the target specified by the legislators. The optimism brought on by the increased presence of women on the slates turned out to be premature (Druciarek et al., 2012, p.20). Roughly one-third of all those elected rans from the top spot of their party's slate. The 2018 election 
were particularly successful for women running as PiS candidates - this was largely the consequence of a high support enjoyed by Law and Justice and the fact that it managed to win more than one mandate in many constituencies, particularly in those regions where the party got an overall majority in a given assembly. It meant that its lower-ranked candidates were far more likely to be elected than in the case of any other formation.

\section{References}

Araújo, C. (2003). Quotas for Women in the Brazilian Legislative System. Paper presented at the International Idea Workshop „The Implementation of Quotas: Latin American Experiences” Lima, Peru, February 23-24, 2003, Retrieved from: https://pdfs.semanticscholar.org/458a/437a8e87e5115faclea85354ce1 a7c1cc7ed.pdf.

Chełstowska, A., Druciarek, M., Niżyńska, A., Skoczylas, N. (2015). Udział kobiet w wyborach parlamentarnych w 2015 roku. Wyniki monitoringu obserwatorium równości ptci. Warsaw: Instytut Spraw Publicznych, Retrieved from: https://pl.boell.org/sites/default/files/udzial_kobiet_wybory_parlamentare_2015_isp_hbs.pdf.

Cichosz, M., Tomczak, Ł. (2018). Implementation of the Quota System in the Regional Assembly Elections: the Analysis of Electoral Results in the Context of Women's Epresentation on Electoral Lists. Przegląd Politologiczny, vol. 4, pp. 25-37.

Cwalina, W., Falkowski, A. (2005). Marketing polityczny. Perspektywa psychologiczna. Gdańsk: Gdańskie Wydawnictwo Psychologiczne.

Dahlerup, D., Freidenvall, L. (2005). Quotas as a 'Fast Track' to Equal Representation for Women. Why Scandinavia is No Longer a Model. International Feminist Journal of Politics, vol. 7 (1), pp. 26-48.

Dahlerup, D., Freidenvall, L. (2010). Judging gender quotas predictions and results. Policy \& Politics, vol. 38 (3), pp. 407-425.

Druciarek, M., Fuszara, M., Niżyńska, A., Zbieranek J. (2012). Kobiety na polskiej scenie politycznej. Warsaw: Instytut Spraw Publicznych.

Druciarek, M., Przybysz, D., Przybysz, I. (2019). Kobiety w polityce lokalnej. Strategie partii politycznych w wyborach samorzadowych $w 2018$ roku. Warsaw: Instytut Spraw Publicznych.

Flis, J. (2012). Skuteczność parytetu. In: A. Turska-Kawa, W. Wojtasik (Eds.), Wybory parlamentarne 2011, Katowice: Remar, pp. 79-102.

Fuszara, M., ed. (2013). Kobiety, wybory, polityka. Warsaw: Instytut Spraw Publicznych.

Fuszara, M. (2012). Kwoty, listy wyborcze i równość plci w wyborach parlamentarnych w 2011 roku. Warsaw: Instytut Spraw Publicznych.

Htun, M. (2002). Women in Political Power in Latin America, International IDEA. Women in Parliament, Stockholm, Retrieved from: https://www.researchgate.net/publication/255617778_Women_in_Political_Power_in_Latin_America.

Kopińska, G. (2018). Stanowiska publiczne jako łup polityczny Polityka personalna w okresie od 16 listopada 2015 do 31 października 2017 roku. Warsaw: Fundacja Batorego, Retrieved from: http://www. batory.org.pl/upload/files/Programy\%20operacyjne/Odpowiedzialne\%20Panstwo/Stanowiska_publiczne_jako_lup_polityczny.pdf.

Kotlarska-Michalska, A. (2011). Społeczne role kobiet. Edukacja Humanistyczna, vol. 1 (24), pp. 25-35.

Krook, M. L. (2004), Reforming Representation: The Diffusion of Candidate Gender Quotas Worldwide. 
Paper presented at the International Studies Association Annual International Convention, Montreal, Canada, March 17-20, Retrieved from: https://sites.hks.harvard.edu/fs/pnorris/Acrobat/stm103\%20 articles/krook_Quotas.pdf.

Krook, M. L. (2007). Candidate gender quotas: A framework for analysis. European Journal of Political Research, vol. 46, pp. 367-394.

Kwiatkowska,A. (2018). Kobiety w wyborach a mechanizmy antydyskryminacyjne - stan aktualny i prognozy na przyszłość. Warsaw: SWPS.

Lesiewicz, E. (2011). Droga polskich kobiet do Parlamentu Europejskiego. Przegląd Politologiczny, vol. 2, p. 55-65.

Marszałek-Kawa, J., Plecka, D. (eds) (2018). Leksykon wiedzy politologicznej. Toruń: Wydawnictwo Adam Marszałek.

Murray, R. (2004). Why Didn't Parity Work? A Closer Examination of the 2002 Election Results. French Politics, vol. 2, pp. 347-362.

Norris, P. (2006). The Impact of Electoral Reform on Women's Representation. Acta Politica, vol. 41 (2), pp. 197-213.

Plecka, D. (ed.) (2018). Demokracja w Polsce po 2015 r., Toruń: Wydawnictwo Adam Marszałek.

Posyłek, M. (2015). Kobiety pilnie poszukiwane- system kwotowy w praktyce na przykładzie wyborców samorzadowych w Częstochowie. Polityka i Społeczeństwo, vol. 3(13), pp. 131-150.

tol/sta (2018.07.06). Kaczyński: do polityki nie idzie się dla pieniędzy. TVN24 bis. Retrieved from: https:// tvn24bis.pl/z-kraju,74/kaczynski-do-polityki-nie-idzie-sie-dla-pieniedzy,851768.html.

Tripp, A. M., Kang, A. (2008). The Global Impact of Quotas: On the Fast Track to Increased Female Legislative Representation. Comparative Political Studies, vol. 41 (3), pp. 338-361.

\section{Authors}

\section{Assoc. Prof. Marzena Cichosz}

University of Wrocław. ORCID: https://orcid.org/0000-0003-0853-742X. Contact details: marzena. cichosz@uwr.edu.pl

\section{Assoc. Prof. Łukasz Tomczak}

University of Szczecin. ORCID: https://orcid.org/0000-0002-6808-0364. Contact details: timczak@ poczta.onet.pl 